DOI: 10.15290/rtk.2018.17.1.03

iD 0000-0002-3969-3954

Rev. Jarostaw Wojtkun

Katolicki Uniwersytet Lubelski Jana Pawła II

\title{
The Natural and Supernatural Dimensions of Priestly Formation
}

On December 8, 2016, the Congregation for the Clergy published a new document on priestly formation entitled The Gift of the Priestly Vocation: Ratio Fundamentalis Institutionis Sacerdotalis on its website. The document introduces new elements of formation while still taking into account the Church's previous teaching on the matter. In particular, the document defines the individual stages of seminary formation as the discipleship stage, the stage of becoming similar to Christ, and the stage of vocational synthesis. Preparation for the priesthood has Christological and pneumatological dimensions where man's natural endowments are assisted by the supernatural dynamics of Christ's grace and in reference to the Holy Trinity. The supernatural dimension of a vocation is emphasized in the very divine nature of the gift that is placed in the heart of a young person. This gift accompanies the seminarian as he is gradually formed into the image of the Good Shepherd and becomes a disciple of the Lord. This process can be lived only in profound submission to the formative action of the Holy Spirit.

Key words: formation, priesthood, seminary, vocation.

The priestly vocation is realized in the dialogue that takes place between God who calls and man who freely responds to God's call. Candidates for the priesthood confirm this reality themselves. They experience the living action of God in their lives as well as Christ's call. Their vocations arise from a personal experience of faith, and the motivation that flows from this faith is one of the most powerfully felt impulses that inclines them to choose the path of life as a priest. 
Moral theology
Faith and the conviction of being called are indissoluble factors that encourage men to enter into formation for the priesthood. Such faith and conviction are permanent elements of a man's decision to enter the seminary, even if the way in which he carries out his priestly service and pastoral models are subject to change as the spirit of the time changes. In today's age, new pastoral challenges are constantly emerging. This reality is often clear in Pope Francis' teaching when he calls for pastoral conversion, for a transformation of pastoral habits, and for priests and people to go out to the existential peripheries of man.

It is within this context that the Congregation for Clergy published the document The Gift of the Priestly Vocation: Ratio Fundamentalis Institutionis Sacerdotalis (hereafter abbreviated as Ratio Fundamentalis) on December 8, 2016. ${ }^{1}$ This document refers not only to the traditional teachings of the Church regarding priestly formation (e.g., Ratio Fundamentalis Institutionis Sacerdotalis, 1985), ${ }^{2}$ it also introduces new elements concerning the context and demands of the present age.

Ratio Fundamentalis refers heavily to Pope John Paul II's PostSynodal Apostolic Exhortation Pastores Dabo Vobis, which presents the preparation for the priesthood in its entirety. ${ }^{3}$ The newest edition of Ratio Fundamentalis, however, points out new dimensions of these stages and pillars and places different emphasis on them. For example, in relation to previous documents that discuss the topic of priestly formation and call the initial phase of priestly preparation the propaedeutic period, Ratio Fundamentalis asserts that this phase is not only necessary, but also obligatory. ${ }^{4}$ Ratio Fundamentalis also focuses on the Christological dimensions of the subsequent phases that go along with the seminarians' philosophical and theological studies and describes them as the "discipleship phase" and the "configurative stage." The document also emphasizes that it is necessary to give the pneumatological process of priestly preparation a clear Christological profile. Everything that a seminarian experiences in his vocation must

1 Congregation for the Clergy, The Gift of the Priestly Vocation: Ratio Fundamentalist Institutionis Sacerdotalis (December 8, 2016). http://www.clerus.va/ content/dam/clerus/Ratio\%20Fundamentalis/The\%20Gift\%20 of\%20the\%20 Priestly\%20Vocation.pdf (10.10.2017). Hereafter abbreviated as RFIS.

Congregation for Catholic Education, Ratio Fundamentalis Institutionis Sacerdotalis (March 19, 1985). http://www.vatican.va/roman_curia/congregations/ ccatheduc/documents/rc_con_ccatheduc_doc_19850319_ratio-fundamentalis_ it.html (10.10.2016). John Paul II, Apostolic Exhortation: Pastores Dabo Vobis (March 15, 1992). 
be accompanied by the dynamism of Christ's grace and constantly referred to the Holy Trinity.

\section{Vocation as a Gift}

Within the very first sentence, the document Ratio Fundamentalis emphasizes the supernatural dimension of a vocation as God's gift. It states: "[t]he gift of the priestly vocation, placed by God in the hearts of some men" 5 can be interpreted as "manifestations of the immeasurable riches of Christ (cf. Eph 3:8)" (11). ${ }^{6}$ The gift of a vocation requires man's response. The first condition, however, is for man to realize the greatness and value of the gift that he has received (34). Pope Francis calls this gift a "diamond in the rough;" just as a diamond needs to be cut and polished, so too does the priestly vocation need to be "carefully polished with respect for the conscience of the candidates and with patience, so that they may shine among the People of God." "God gives the person called the "diamond" of a vocation, but this diamond will not shine as it should if the one who receives the gift does not work on himself and "polish" his vocation.

In order to avoid emphasizing the natural dimension over the supernatural dimension of a vocation (or vice versa), it is necessary for formators and seminarians to be aware of the nature of a vocation as a gift from God. For, example, sometimes the anthropological, psychological, and cultural dimensions of a vocation can be emphasized to the detriment of the religious dimension. Or, the spiritual and religious dimension of a vocation can be emphasized to the detriment of the natural dimension. This occurs when an individual does not take into account knowledge of his own nature, its deficiencies, the conditions of his history, and psychic factors, and, instead, tends toward "disembodied spiritualism." 8

How can individuals protect themselves against this harmful dichotomy? On the $60^{\text {th }}$ anniversary of his ordination to the priesthood, Pope Emeritus Benedict XVI emphasized that it is absolutely necessary

$5 \quad$ RFIS, pg. 1.

6 For ease of reference, the paragraph numbers of RFIS are included in the main body of the text of this article.

7 Francis, Address to the Plenary of the Congregationfor the Clergy,(October 3,2014), https://w2.vatican.va/content/francesco/en/speeches/2014/october/documents/ papa-francesco_20141003_plenaria-congregazione-clero.html (05.04.2018).

8 G. Cucci, H. Zollner, Un nuovo documento sulla formazzone sacerdotale [The New document on Priestly Formation], La Civiltà Cattolica (March 25/April 8, 2017), pg. 63. 
Moral theology

for individuals to cultivate the bond of friendship with Christ. In this sense, he pointed out the importance of the natural conditions of one's vocation along with the simultaneous awareness of the greatness of the gift of friendship that Christ offers:

He calls me his friend. He welcomes me into the circle of those he had spoken to in the Upper Room, into the circle of those whom he knows in a very special way, and who thereby come to know him in a very special way. He grants me the almost frightening faculty to do what only he, the Son of God, can legitimately say and do: I forgive you your sins. [...] I know that behind these words lies his suffering for us and on account of us. I know that forgiveness comes at a price: in his Passion he went deep down into the sordid darkness of our sins."

\section{A Christological Perspective}

Pope Emeritus Benedict XVI's aforementioned words clearly provide a Christological perspective of priestly formation. Personal friendship with Christ has the power to change man's entire existence by constantly increasing the credibility of his witness to the Gospel. A deep relationship with Christ leads to a "gradual grounding of the seminarian in the likeness of the Good Shepherd" (69). In the Vatican document, this "grounding" is defined as the "the heart of [the seminarians'] spiritual formation" (102). This relationship is obviously connected with a love for God's word. The document recalls St. Jerome's words that "Ignorance of Scriptures is ignorance of Christ.' Therefore, a relationship with the Word of God holds a preeminent place in the process of spiritual growth. Before it is ever preached, the Word must be welcomed in the depth of the heart [...]" (103).

This fundamental truth is an indispensible condition for effectively preaching God's word. God's word is also a gift, and it should be received and shared as a gift. "God is so humble that he uses us to spread his word. We become his voice, once we have listened carefully to the word coming from his mouth. We place his word on our lips in order to bring it to the world. He accepts the offering of our prayer and through it he communicates himself to everyone we meet." 10

$9 \quad$ Benedict XVI, "Benedict XVI: A Time of Thanksgiving for 60 Years of Priesthood," (June 29, 2011), http://www.asianews.it/news-en/Benedict-XVI:-a-timeof-thanksgiving-for-60-years-of-priesthood-21966.html (Accessed: 06.05.2018).

10 Benedict XVI, Homily of His Holiness Benedict XVI, Celebration of Vespers with Priests, Religious People, Seminarians and Deacons (September 12, 2008). https://w2.vatican.va/content/benedict-xvi/en/homilies/2008/documents/hf_benxvi_hom_20080912_parigi-vespri.html (05.04.2018). 
A Christological perspective gives direction not only to priestly formation, but it also is the central principle of all of Christian moral life. This perspective is expressed by the idea of imitating Christ, who, for Moral theology John Paul II, is the "essential and primordial foundation of Christian morality."11 Pope John Paul specifies that this imitation depends not on externally reproducing Jesus' behavior, nor in simple obedience to Jesus' commandments, but rather on something much deeper and more radical. Imitation of Christ means "holding fast to the very person of Jesus, partaking of his life and his destiny, sharing in his free and loving obedience to the will of the Father."12

Christ invites the person called to adhere closely to Him. The quality of this adherence depends, however, on the candidate's personal effort to form in himself attitudes that prove that he has a mature personality. Christ's attitudes show man the way to form the same attitudes in himself. A well-formed humanity is comprised of a group of features that allow one to verify the direction of the maturation process. In a number of places, Ratio Fundamentalis specifies these features by name: friendship with Christ bears fruit in humble submission that is understood as "availability to others and concern for the common good; obedience, lived as trustful listening; youthful chastity, as a sign of the transparency of relationships and the gift of self; and poverty as formation in the temperate use of material things and in a life of simplicity" (21). Pastoral care of the faithful must be accompanied by the following: an ability to establish mature relationships with others in order to be a person of communion and dialogue, and an ability to sacrifice oneself and be generous (41). The prospect of authentically carrying out priestly ministry requires practice in humility, courage, common sense, magnanimity, right judgment, discretion, tolerance, love of truth, and honesty (93).

Aesthetics and a sense of beauty play an important role in the process of forming men with mature attitudes (94). A sense of beauty gives a man insight into his relationship with God. Beauty expresses something more about man and about his life in an otherwise inexpressible way. A sense of beauty allows human sensitivity, imagination,

\footnotetext{
11 John Paul II, Encyclical: Veritatis Splendor (August 6, 1993), 19. http://w2.vatican. va/content/john-paul-ii/en/encyclicals/documents/hf_jp-ii_enc_06081993_veritatis-splendor.html (05.04.2018).

Ibid.
} 
Moral theology

and feelings to create a harmonious space that expresses the whole of the physical and spiritual dimension of man. ${ }^{13}$

\section{The Way of Discipleship}

Priestly formation is one continual process that can be divided into two periods: initial formation in the seminary and ongoing formation after ordination. These are two phases of one and the same reality.

The formation of which we speak is an experience of permanent discipleship, which draws one close to Christ and allows one to be ever more conformed to Him. Therefore, it has no end, for priests never stop being disciples of Jesus, they never stop following Him. Thus, formation understood as discipleship sustains the ordained minister his entire life and regards his entire person and his ministry. Initial and ongoing formation are two aspects of one reality: the path of the disciple priest, in love with his Lord and steadfastly following Him. ${ }^{14}$

This point of view of formation is necessary if priestly ministry is to be fruitful. If the priestly role is not to be reduced to the function of an administrator who runs the parish, then it is necessary perceive the priesthood as a form of permanent discipleship: "The priest is a disciple who is always on the path. He is appointed a shepherd and guide of the people only when he is the first to put his life at the disposal of the Lord and His word." 15

As a principle of priestly formation, the path of discipleship begins much earlier than the moment a young man enters the seminary with the Sacrament of Baptism, and it is strengthened and confirmed in the Sacrament of the Eucharist. Entering the seminary is a decision through which the Eucharist "comes to be appreciated as the centre of one's life [...] and continues through the whole life" (pg. 3). Priestly formation, which is an experience of discipleship, "cannot be a limited task, because priests never stop being disciples of Jesus, who follow Him. Sometimes we proceed with celerity, at other times our step

13 See G. Cucci, H. Zollner, "Un nuovo documento sulla formazone sacerdotale," pg. 64 .

14 Francis, Letter of His Holiness Pope Francis the Participants of the in the Extraordinary General Assembly of the Italian Episcopal Conference (November 8, 2014). https://w2.vatican.va/content/francesco/en/letters/2014/documents/ papa-francesco_20141108_lettera-cei.html (05.04.2018). A part of this letter was included in paragraph 91 of RFIS.

15 J. C. Patrón Wong, Presentazione della Ratio Fundamentalis Institutionis Sacerdotalis ai Formatori dell'Emilia Romagna, http://www.clerus.va/content/dam/ clerus/Dox (December 10, 2018). 
is hesitant, we stop and we may even fall, but always staying on the path. Therefore, formation understood as discipleship accompanies the ordained minister his entire life and regards his person as a whole, intellectually, humanly and spiritually."16

What gives priestly formation this perspective? To what does it lead? If we accept St. John Paul II's understanding of this term, then we can say that priestly formation instills in men an attitude of service: "Being a follower of Christ means becoming conformed to him who became a servant even to giving himself on the Cross (cf. Phil 2:5-8)."17 Ratio Fundamentalis adds that priestly formation aims to form men in the image of Christ the Good Shepherd..$^{18}$ The person of Jesus Christ is always at the center of the formation of a person's personality. In this way, formation is about forming a person's heart and personality traits according to Jesus' heart: "We are called to have the same sensitivity as Jesus-his way of feeling, his emotions, his desires, his tastes, his sentiments, his interests, and the same criteria against which we make decisions. [...] this is necessary in order for the heart to be transformed." 19

The importance of this concept of formation is clear simply by the number of times the document mentions the primacy of the heart. Preparation for priesthood primarily consists in forming the heart of the priest (55), and this formation should mould the heart according to the example of the heart and life of Jesus (40). This process is never complete because it "implies a continuous conversion of heart" (56). The factor that integrates all dimensions of formation is "transforming' or 'assimilating' the heart in the image of the heart of Christ, who was sent by the Father to fulfill his loving plan. He was moved when face with human suffering (cf. Mt 9:35-36), he went to seek out the lost sheep (cf. Mt. 18: 20-24)" (89).

If the heart of Jesus is the only point of reference for a seminarian's formation, then it is important to understand what this concept means. What does Jesus desire and why does he go out? Two references to St. Matthew's Gospel provide important hints to the answers to this

16 Francis, Address of Pope Francis to the Plenary of the Congregation for the Clergy (October 3, 2014), 30. https://w2.vatican.va/content/francesco/en/speeches/2014/ october/documents/papa-francesco_20141003_plenaria-congregazione-clero. html (05.04.2018).

17 John Paul II Veritatis Splendor, 21.

18 The image of Christ as the Good Shepherd appears in, among others, numbers $69,84,89,103$, and 120 .

19 A. Cencini, Kryzys - godzina Boga, Cracow 2017, pgs. 20-21. 
Moral theology

question. The miraculous multiplication of the loves, which is found in Matthew 9, is rooted in Jesus' mercy, which "does not divide reality into two realms: the realm of the Kingdom of God and the realm of ordinary life. [Jesus' mercy] does not permit such a realistic demarcation. Everything - all of human existence, including food-belongs to the Kingdom of God." ${ }^{20}$ This perspective reveals that caring for the material needs of the faithful and showing charity to the poor and homeless are not a luxury that only the most fervent pastors can afford. Rather performing these acts of mercy demonstrates that a person takes seriously the principles of forming a priestly heart according to the example of the heart of Christ.

Moreover, the parable about the lost sheep in Matthew 18 presents the image of the Good Shepherd whose love includes not just humanity as a whole, but every individual human being.

It is important that Jesus sought out the one lost sheep and, through this act, emphasized that each and every individual person is important to God. God does not seek the mass of people; he seeks each individual person in his unique personality. God knows each of us by name. God is really the God of us as individual persons; therefore, we must seek out each person who allows himself to be found by the true shepherd. The Lord set out to find me and, in seeking me, experienced tiredness. Because of me he endured many difficulties, and for me he took up the cross. ${ }^{21}$

Seminarians should not limit their formation to studying the exterior behavior of priests, even if their behaviors demonstrate the cultivation of their intellectual and pastoral abilities. For, such behaviors can simply be a "veneer of virtuous habits" (41) and are not able to overcome "spiritual worldliness, which hides behind the appearance of piety and even love for the Church, [and] consists in seeking not the Lord's glory but human glory and personal well-being." 22 This worldliness manifests itself in such attitudes as:

obsession with personal appearances, a presumed theological or disciplinary certainty, vain doctrinal certainty, narcissism and authoritarianism, the attempt to dominate others, a merely external and ostentatious

\footnotetext{
20 A. Paciorek, Ewangelia wedtug św. Mateusza, Chapters 14-28. Komentarz, Part II, Edycja Świętego Pawła 2008, pg. 45.

21 J. Ratzinger, Jezus z Nazaretu. Studia o chrystologii in Opera omnia Tom VI/2, Lublin 2015: pg. 1064. Pope Francis continuously encourages the members of the Church to serve pastorally by going out to those on the periphery.

22 Francis, Apostolic Exhortation: Evangelii Gaudium (November, 26 2013), 93. https://w2.vatican.va/content/francesco/en/apost_exhortations/documents/papafrancesco_esortazione-ap_20131124_evangelii-gaudium.html (05.04.2018).
} 
preoccupation with the liturgy, vainglory, individualism, the inability to listen to others, and every form of careerism (42).

Moreover, seminarians need to develop in themselves the feelings and sensitivity of Jesus Christ. The path of conforming oneself to Christ must lead to a deep friendship with Him, which means sharing His feelings (41), since they must be projected onto the attitudes and training of pastoral service.

Which of Christ's feelings should priests and candidates for the priesthood imitate? When speaking to the Roman clergy, Pope Francis pointed out that:

\begin{abstract}
Priests are moved to compassion before the sheep, like Jesus, when he saw the people harassed and helpless, like sheep without a shepherd. Jesus has the "bowels" of God, Isaiah speaks about it very much: he is full of tenderness for the people, especially for those who are excluded, that is, for sinners, for the sick who no one takes care of.... Thus, in the image of the Good Shepherd, the priest is a man of mercy and compassion, close to his people and a servant to all. This is a pastoral criterion I would like to emphasize strongly: closeness. Closeness and service, but closeness, nearness! $!^{23}$
\end{abstract}

\title{
The Pneumatological Perspective of Formation
}

This rather extensive and ambitious work of human formation is limited only to the natural course of development. Rather, if future priests are to become bridges that connect people with God and to reflect the feelings of Christ, then Christ's perfect humanity must serve as the source and model (93).

Are these goals not too high? Is Jesus Christ and His perfect humanity as the goal of human formation a model that man, in his natural abilities, is unable to follow? The evangelical idea of Christ's humanity can be understood as too great a goal to achieve. This would be the sign of a culture that doubts man's abilities and believes that man would not be able to make irrevocable decisions and enter into life-long commitments; he would not be able to remain faithful in marriage or in the priesthood. Even the Commandments, the requirements of the Gospel would be unattainable and beyond the reach of man's abilities. The former Prefect for the Congregation for the Doctrine of the Faith, Cardinal Gerhard Mueller, emphatically stated that this is not true:

23 Francis, Address of Pope Francis to the Priests of the Diocese of Rome, https:// w2.vatican.va/content/francesco/en/speeches/2014/march/documents/papafrancesco_20140306_clero-diocesi-roma.html (05.04.2018). 
Moral theology

"God can demand such love because he loved us first. He promised that he would assist us with his grace. Even if man does not remain faithful to his duties, this is not due to a lack of grace, but rather to a lack of humility to implore God's grace." 24

Man does not depend exclusively on his own abilities in this process of growth. Rather, a sacramental and liturgical life is indispensible in this process. Human maturation, on the other hand, takes place through man's own effort as well as the support of Christ's grace, through which one gains the ability to go beyond the limits of one's own nature, weaknesses, and external circumstances (43). This principle applies not only to priestly formation, but to Christian life in general. In his reflection inspired by the dialogue between the rich young man and Jesus (Mt 19:15n), Pope John Paul II asserted: "To imitate and live out the love of Christ is not possible for man by his own strength alone. He becomes capable of this love only by virtue of a gift received." ${ }^{25}$ A little further on, Pope John Paul II repeated this same idea in a slightly different way: "Love and life according to the Gospel cannot be thought of first and foremost as a kind of precept, because what they demand is beyond man's abilities. They are possible only as the result of a gift of God who heals, restores and transforms the human heart by his grace." 26 This gift is above all the grace of the Holy Spirit. The seminarian's path of discipleship, therefore, can be lived out only in profound docility to the formative action of the Holy Spirit "which gradually moulds him in the image of the Master" (42). The supernatural dimension of the means of formation is clearly outlined here: "Personal accompaniment, which has docibilitas to the Holy Spirit as its goal, is an indispensible means of formation" (45).

The particular stages in which this docibilitas ${ }^{27}$ comes to the fore are during the ministries of lector and acolyte. The lectorate "challenges the seminarian to allow himself to be transformed by the Word of God, the object of his prayer and study. The conferral of the ministry of acolyte implies a deeper participation in the mystery of Christ, who gives Himself and is present in the Eucharist" (72). In addition to being open

24 G. L. Müller, Indagine sulla speranza. Dialogo con Carlos Granados, Contagalli 2017, pg. 178. The Cardinal spoke these words in response to a question that was posed to him regarding today's concept of marriage, but his response also pertains to the demands of priestly life.

John Paul II, Veritatis Splendor, 22.

Ibid, 23.

This word does not have a proper equivalent in English; therefore, the Latin word is used even in RFIS. 
to the action of the Holy Spirit, seminarians should make use of the natural means to train their character and work on their personalities. Human formation and maturity objectively condition the holiness of the presbyterate and the candidates for priesthood (63).

Ratio Fundamentalis describes the interdependence between the human and divine elements of formation as an interior and creative synthesis between that which is weak (the human personality and its limitations) and that which is strong (the grace of the Holy Spirit) (see 29). Two closely connected elements make up the reality of a vocation: the gift of God and man's responsible cooperation with God by cultivating the gift that God has given to him. God unfailingly grants the grace of a vocation and the means to develop it. The outcome of this "synthesis" between the call and the means depends in large measure on how much one nurtures his vocation. Ratio Fundamentalis anticipates that individuals will waste the gift of their vocation in the absence of proper care. Essentially, the "lack of a well-structured and balanced personality is a serious and objective hindrance to the continuation of formation for the priesthood" (63). ${ }^{28}$ Man must respond to his vocation, which is a gift from God, and this response must involve all dimensions and dynamics of his nature. God does not revoke his gifts, but man can waste God's gifts. A call from God must be cultivated. Ratio Fundamentalis foresees situations in which seminary formation should cease: when a vocation was not properly discerned as a priestly vocation, ${ }^{29}$ or when a vocation "may not have been cultivated sufficiently" (72).

The requirement to nurture one's vocation does not end once a man has been ordained to the priesthood. Rather, the need to nurture one's vocation lasts throughout a priest's life and into the later stages of his priesthood. In the part of Ratio Fundamentalis dedicated to permanent formation (84), the document points out the challenges associated with the nature of contemporary culture and social life. For example, the experience of one's weakness, the risk of feeling like a dispenser of

$28 \quad$ Sometimes a seminarian's lack of cooperation with God's gift makes it necessary for his superior to tell him what is contained in the Church document on whether people with homosexual tendencies are fit to become priests and religious - a statement that applies to this situation as well: "The desire alone to become a priest is not sufficient, and there does not exist a right to receive sacred ordination." See Congregation for the Doctrine of the Faith, Instruction Concerning the Criteria for the Discernment of Vocations with Regard to Persons with Homosexual Tendencies in View of Their Admission to the Seminary and to Holy Orders, (November 4, 2005), 3.

29 According to the authors of RFIS, it is not rare for men to mistakenly think that they have a vocation to the priesthood. This may be due to "confusion between the sequela Christi and the call to the ministerial priesthood" (24). 
Moral theology

sacred things, the challenges of celibacy, tiredness and physical frailty that come with age, and the burden of routine can have an effect on the fruitfulness of the grace of a priestly vocation (84).

How can a priest protect himself from these dangers? When referring to the content of Ratio Fundamentalis, the Prefect for the Congregation on the Clergy, Cardinal Beniamino Stella, clearly points to the primacy of priestly spirituality:

The [consciousness] of priestly identity is necessarily founded upon this aspect: the priest is not a man of action, a leader, religious organiser, or a functionary of the sacred. Instead he is a disciple passionately in love with the Lord, whose life and whose ministry are founded on this intimate relationship with God and upon his configuration to Christ the Good Shepherd. Only in this way - cultivating his spiritual life with discipline and expressly dedicated time - can old sacral and bureaucratic views of ministry be surpassed, so that we may have [p]riests passionately motivated by the Gospel, capable of 'feeling with the Church' and being, like Jesus, compassionate and merciful 'Samaritans. ${ }^{30}$

\section{Environmental Conditions}

An awareness of the indispensible place of God's grace in the formation process should also be cultivated in places where the priestly vocation develops. Since the natural and supernatural dimensions of a vocation are intertwined, a vocation cannot be realized when it is separated from an individual's concrete reality, history, and environmental conditions. Essentially, we find not only ourselves but also God himself in the story of our lives. For, "[1]ife can be compared to a book in which the days and activities constitute the books individual pages, and where God's words are the footnotes that explain the content. ${ }^{31}$ " God adds His "footnotes" to the history of man's vocation, and these footnotes make it easier for man to properly see that God acts in the story of his own life. In this way, the soil in which the grain of a vocation grows becomes more fertile. Pope Francis is convinced that

Wherever there is life, fervor and a desire to bring Christ to others, genuine vocations will arise. Even in parishes where priests are not particularly committed or joyful, the fraternal life and fervour of the

\footnotetext{
30 Interview with the Prefect of the Congregation of the Clergy His Eminence, Beniamino Cardinal Stella (December 7, 2016), http://www.clerus.va/content/ $\mathrm{dam} / \mathrm{clerus} /$ Ratio $\% 20 \mathrm{Fundamentalis} /$ Interview $\% 20-\% 20 \mathrm{The} \% 20 \mathrm{Gift} \% 20 \mathrm{of} \% 20$ Priestly\%20Vocation.pdf (05.04.2018).

31 G. Cucci, H. Zollner, Un nuovo documento sulla formazone sacerdotale, 64.
} 
community can awaken in the young a desire to consecrate themselves completely to God and to the preaching of the Gospel. ${ }^{32}$

Even though people and places play a somewhat external role in this process, their role is always connected with the dynamics of God's own action. Neither superiors nor seminarians play the most important role in priestly formation; rather, the "principle agent of priestly formation is the Most Holy Trinity, who shapes every seminarian according to the plan of the Father, both through the presence of Christ in His word, in the sacraments and in the brothers and sisters of the community, and through the many actions of the Holy Spirit" (125). The seminarians themselves, however, should feel like they are the protagonists of their own formation, whether it takes place in the broad context of formative environments such as the parish, the diocesan clergy, and the community of educators in the seminary (130).

Ratio Fundamentalis also speaks about the importance of the community, meaning the social environment in which priestly formation takes place. A vocation arises from faith, and faith does is not born in a spatial void. Outside of the family, the experience of faith occurs in the parish. At the same time, formative roles are divided between the different parish environments with which the Seminary is connected in many ways. Both a seminarian's home parish as well as the one with which he is currently connected give rise to, maintain, and strengthen his vocation (148). The decision to admit a seminarian to ordination should be made after first seeking the opinion of the pastor of a seminarian's home parish or the parish with which he is territorially affiliated (205). Ratio Fundamentalis also mentions that the seminarian's family's parish community in which he was involved should also experience a time of preparation before his ordination (78).

The categories listed above are not always found in one parish. For example, sometimes a seminarian's parish of origin is not the same as the parish with which he is territorially affiliated.$^{33}$ In other words, a seminarian could come from one parish but be connected with another parish where he discovered and grew in his own vocation. To what extent, therefore, should the participation of each of these communities be taken into consideration during the formation process? This question is still open for discussion and relevant to the issues presented in this article. Ratio Fundamentalis responds only partially to

32 Francis, Evangelii Gaudium, 107.

33 The author of this article is aware from his own personal experience working with seminarians that situations arise wherein a seminarian may feel more connected to a parish other than the one in the territory in which he resides. 
Moral theology

this question by stating that formation depends on both supernatural means and those means written in the seminarian's personal history that took place where he grew up. The parish has an essential place in this process. However, when more than one parish is involved, conflicts can arise from a misunderstanding of the "formation jurisdiction" of individual parishes with regard to a particular seminarian. Unfortunately, such conflicts can have a decidedly negative impact on the course of the formation process.

In addition to discussing the parish environment's role in shaping the seminarian's personality so that it can mature, Ratio Fundamentalis also discusses the role of social media. Seminarians should know how to use social media, and social networks (100) should be integrated into seminaries, since contact with the digital world is an integral part of a seminarian's development (97).

The four pillars of formation (human, spiritual, intellectual, and pastoral) that the aforementioned documents recognize as the foundation, heart, means, and aims of formation are involved in the four dimensions of one and the same formation process. The gift of a vocation to the priesthood must be nurtured and properly directed on the path of discipleship to such a degree that candidates for the priesthood take on and reflect the attitudes and feelings of Christ. Such formation cannot be accomplished other than through the candidate's cooperation with grace, which he receives through his submission to the Holy Spirit. Therefore, living out and growing in one's vocation is not a matter only for the one who is called, who has at his disposal the natural means for growing in such a vocation. Rather, the candidate must also take advantage of the means of the grace that is given to him in the Church in order to grow in his vocation and fulfill its purpose.

\section{WSPÓŁUDZIAŁ WYMIARU NADPRZYRODZONEGO I NATURALNEGO W FORMACJI KAPŁAŃSKIEJ}

8 grudnia 2016 roku na stronie internetowej Kongregacji ds. Duchowieństwa został opublikowany nowy dokument na temat formacji kapłańskiej, Ratio fundamentalis institutionis sacerdotalis. Wprowadza on pewne nowe elementy, biorąc pod uwagę dotychczasowe nauczanie Kościoła. Jednym 
z nich jest określenie poszczególnych etapów seminaryjnego przygotowania jako etap bycia uczniem, etap upodabniający do Chrystusa i okres syntezy powołaniowej. Przygotowanie do kapłaństwa ma zatem swój profil chrystologiczny i pneumatologiczny. Naturalnemu wyposażeniu człowieka towarzyszy nadprzyrodzony dynamizm łaski Chrystusa i stałe odniesienie do Trójcy Świętej. Wymiar nadprzyrodzony powołania jest uwypuklony w samej naturze Bożego daru złożonym w sercu młodego człowieka. Towarzyszy mu w stopniowym kształtowaniu fizjonomii Dobrego Pasterza, stawania się uczniem Pana. Ten proces może być przeżywany jedynie w głębokiej uległości na formacyjne oddziaływanie Ducha Świętego.

Słowa kluczowe: formacja, kapłaństwo, seminarium, powołanie.

\section{Bibliography:}

1. Benedict XVI, Benedict XVI: A Time of Thanksgiving for 60 Years of Priesthood, (June 29, 2011), http://www.asianews.it/news-en/Benedict-XVI:-atime-of-thanksgiving-for-60-years-of-priesthood-21966.html (Accessed: 06.05.2018).

2. Benedict XVI, Homily of His Holiness Benedict XVI, Celebration of Vespers with Priests, Religious People, Seminarians and Deacons (September 12, 2008). https://w2.vatican.va/content/benedict-xvi/en/homilies/2008/documents/hf_ben-xvi_hom_20080912_parigi-vespri.html (05.04.2018).

3. Cencini A.., Kryzys - go $\bar{d} z i n a$ Boga, Cracow 2017.

4. Congregation for the Clergy, Ratio Fundamentalis Institutionis Sacerdotalis (March 19, 1985).

5. Congregation for the Doctrine of the Faith, Instruction Concerning the Criteria for the Discernment of Vocations with Regard to Persons with Homosexual Tendencies in View of Their Admission to the Seminary and to Holy Orders, (November 4, 2005).

6. Cucci G., Zollner H., Un nuovo documento sulla formazione sacerdotale, "La Civiltà Cattolica" (March 25-April 8, 2017).

7. Francis, Apostolic Exhortation: Evangelii Gaudium (November 26, 2013).

8. Francis, Letter of His Holiness Pope Francis the Participants of the in the Extraordinary General Assembly of the Italian Episcopal Conference (November 8, 2014). https://w2.vatican.va/content/francesco/en/letters/2014/documents/papa-francesco_20141108_lettera-cei.html. Accessed: 05.04.2018.

9. Francis, Address of Pope Francis to the Plenary of the Congregation for the Clergy (October 3, 2014), 30. https://w2.vatican.va/content/francesco/en/ speeches/2014/october/documents/papa-francesco_20141003_plenariacongregazione-clero.html (Accessed: 05.04.2018).

10. Francis, Address of Pope Francis to the Priests of the Diocese of Rome, https://w2.vatican.va/content/francesco/en/speeches/2014/march/documents/papa-francesco_20140306_clero-diocesi-roma.html. Accessed: 05.04.2018. 
Moral theology

11. Interview with the Prefect of the Congregation of the Clergy His Eminence, Beniamino Cardinal Stella (December 7, 2016), http://www.clerus.va/ content/dam/clerus/Ratio\%20Fundamentalis/Interview\%20-\%20The\%20 Gift\%20of\%20Priestly\%20Vocation.pdf. Accessed: 05.04.2018.

12. John Paul II, Encyclical: Veritatis Splendor (August 6, 1993).

13. John Paul II, Apostolic Exhortation: Pastores Dabo Vobis (March 25, 1992).

14. Congregation for the Clergy, The Gift of the Priestly Vocation: Ratio Fundamentalist Institutionis Sacerdotalis (December 8, 2016). http://www. clerus.va/content/dam/clerus/Ratio\%20Fundamentalis/The\%20Gift\%20 of\%20the\%20Priestly\%20Vocation.pdf. Accessed: 10.10.2017.

15. Müller G. L., Indagine sulla speranza. Dialogo con Carlos Granados, Contagalli 2017.

16. Paciorek A., Ewangelia wedtug św. Mateusza, Chapters 14-28. Commentary, Part II, Edycja Świętego Pawła 2008.

17. Patrón Wong J. C., Presentazione della Ratio Fundamentalis Institutionis Sacerdotalis ai Formatori dell'Emilia Romagna, http://www.clerus.va/ content/dam/clerus/Dox (December 10, 2018).

18. Ratzinger J., Jezus z Nazaretu. Studia o chrystologii, Opera Omnia Vol. VI/2, Lublin 2015. 